\section{Commentary: When we don't know what we don't know}

\author{
Gaetano Paone, MD, MHSA
}

In this issue of JTCVS Techniques, He and Raman ${ }^{1}$ present the case of a 67-year-old male admitted with unstable angina and non-ST elevation myocardial infarction along with, among other comorbidities, idiopathic pulmonary fibrosis for which he is receiving the antifibrotic drug nintedanib. The patient underwent isolated coronary artery bypass surgery using both a pedicled left internal mammary artery and a radial artery harvested in an open manner. Nintedanib was restarted on postoperative day 2, and the patient was discharged on day 6 after an uncomplicated hospital stay. He returned several weeks later with sterile dehiscence of both the sternal incision and the radial artery harvest site. Over an undefined time course, both wounds were treated with vacuum-assisted dressing changes and then successfully reclosed, with confirmed healing at 6-week and 7-month follow-ups.

By inhibiting multiple receptor tyrosine kinases, including platelet-derived growth factor receptors $\alpha$ and $\beta$, fibroblast growth factor receptors 1 to 3 , and vascular endothelial growth factor receptors 1 to 3 , nintedanib exhibits potent antifibrotic and anti-inflammatory activity. ${ }^{2,3}$ With this knowledge, it might then be expected that early postoperative reinstitution would impair postoperative wound healing and warrant withholding as necessary. That said, the most common side effects associated with use of nintedanib are diarrhea, nausea, and vomiting. ${ }^{4,5}$ Owing to a lack of experience in the postoperative setting, there is essentially no mention of wound healing complications, save for within a "Product Mono-

\footnotetext{
From the Division of Cardiothoracic Surgery, Structural Heart and Valve Center, Emory University School of Medicine, Atlanta, Ga.

Disclosures: The author reported no conflicts of interest.

The Journal policy requires editors and reviewers to disclose conflicts of interest and to decline handling or reviewing manuscripts for which they may have a conflict of interest. The editors and reviewers of this article have no conflicts of interest.

Received for publication Nov 9, 2020; revisions received Nov 9, 2020; accepted for publication Nov 20, 2020; available ahead of print Nov 30, 2020.

Address for reprints: Gaetano Paone, MD, MHSA, Division of Cardiothoracic Surgery, Structural Heart and Valve Center, Emory University Midtown Hospital, 550 Peachtree St, NE, Davis-Fischer Bldg, 4th floor, Atlanta, GA 30308 (E-mail: gaetano.paone@emory.edu).

JTCVS Techniques 2021;6:102-3

2666-2507

Copyright (c) 2020 The Authors. Published by Elsevier Inc. on behalf of The American Association for Thoracic Surgery. This is an open access article under the CC BY-NCND license (http://creativecommons.org/licenses/by-nc-nd/4.0/).

https://doi.org/10.1016/j.xjtc.2020.11.025
}

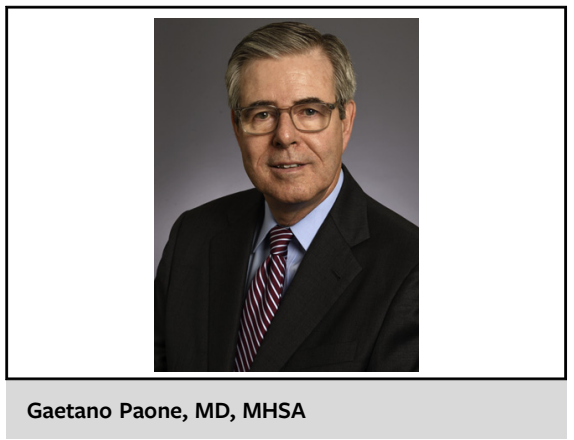

CENTRAL MESSAGE

Not recognizing a lack of familiarity with a drug and its side effects results in a failure of wound healing after coronary bypass surgery.

graph"6 included within the authors references, which states that nintedanib "may impair wound healing", and that when stopped preoperatively, should then be "resumed based on clinical judgement of adequate wound healing."

Allowing that determining the "exact causality" of sternal dehiscence can be difficult, the authors reasonably suggest that the occurrence of sterile dehiscence of both wounds in their patient is likely related to the reinitiation of nintedanib on postoperative day 2 . Indeed, given its antifibrotic properties, the drug may well be responsible for this failure of wound healing. To that end, after pulmonary consultation, the drug was stopped during readmission, and subsequent wound healing occurred without incident. Less convincing is an implied benefit to the use of rigid plating to reclose the sternum, particularly as the presumed offending drug was removed and closure was combined with pectoralis major advancement flaps. But I digress.

The authors acknowledge that a failure to initially investigate the mechanism of action and potential side effects of a drug with which they were unfamiliar may well have led to this potentially avoidable complication. In arguably his most memorable public statement, former Secretary of Defense Donald Rumsfeld alluded to the concept of "unknown unknowns," referring to them as "the ones we don't know we don't know."7 Clearly, the authors did not recognize the need to know more about nintedanib before bypass surgery. I suspect that going forward, they will remember there are things "we don't know we don't know" and proceed 
accordingly. Hopefully, by learning from rather than repeating their miscalculation, so too will we all.

\section{References}

1. He C, Raman J. Wound dehiscence with nintedanib after cardiac surgery: a cautionary tale. J Thorac Cardiovasc Surg Tech. 2021;6:99-101.

2. Betensley A, Sharif R, Karamichos D. A systematic review of the role of dysfunctional wound healing in the pathogenesis and treatment of idiopathic pulmonary fibrosis. J Clin Med. 2016;6:2.

3. Wollin L, Wex E, Pautsch A, Schnapp G, Hostettler KE, Stowasser S, et al. Mode of action of nintedanib in the treatment of idiopathic pulmonary fibrosis. Eur Respir J. 2015;45:1434-45.
4. Boehringer Ingelheim Pharmaceuticals. Highlights of prescribing information: $\mathrm{OFEV}^{\circledR}$ (nintedanib). Available at: https://www.accessdata.fda.gov/drugsatfda_ docs/label/2014/205832s000lbl.pdf. Accessed November 7, 2020.

5. Flaherty KR, Wells AU, Cottin V, Deveraj A, Walsh SLF, Inoue Y, et al. Nintedanib in progressive fibrosing interstitial lung diseases. $N$ Engl J Med. 2019;381: 1718-27.

6. Boehringer Ingelheim Ltd. OFEV (Nintedanib) product mongraph. Available at: https://www.boehringer-ingelheim.ca/sites/ca/files/ofevpmen_4.pdf. Accessed July $11,2020$.

7. Graham DA. Rumsfeld's knowns and unknowns: the intellectual history of a quip. The Atlantic. Available at: https://www.theatlantic.com/politics/archive/2014/03/ rumsfelds-knowns-and-unknowns-the-intellectual-history-of-a-quip/359719/. Accessed November 7, 2020. 